\title{
Corrigendum
}

\section{Emerging concepts: linking hypoxic signaling and cancer metabolism}

CA Lyssiotis, MG Vander-Heiden, C Muñoz-Pinedo and BM Emerling

Cell Death and Disease (2012) 3, e329; doi:10.1038/cddis.2012.75; published online 21 June 2012

Correction to: Cell Death and Disease (2012) 3, e303; doi:10.1038/cddis.2012.41; published online 3 May 2012

Since the publication of this article the authors have noticed MG Vander-Heiden name was incorrect. The error has now been rectified. The article with the corrected authors list appears online, together with this corrigendum.
The authors would like to apologize for this error.

(c) Cell Death and Disease is an open-access journal published by Nature Publishing Group. This work is licensed under the Creative Commons Attribution-NonCommercial-No Derivative Works 3.0 Unported License. To view a copy of this license, visit http://creativecommons.org/licenses/by-nc-nd/3.0/ 